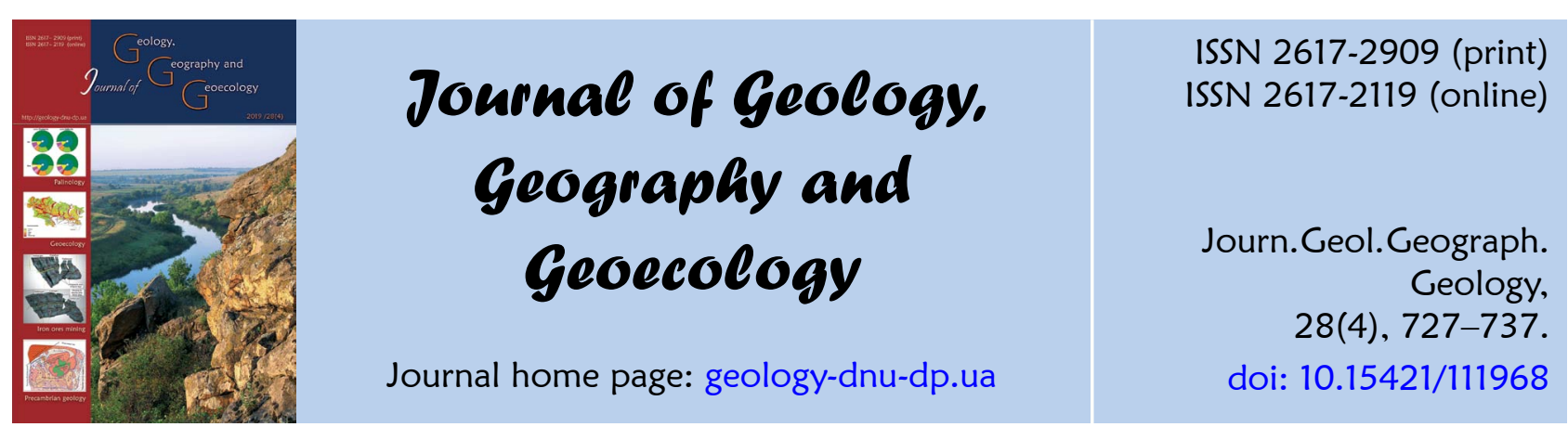

Olena A. Sirenko

Journ. Geol. Geograph. Geoecology, 28(4), 727-737.

\title{
Palynological data on the description of the Gelasian and Calabriane analogues in the strato- type section of the Kuyalnik deposits near Kryzhanivka village (Odessa region)
}

\author{
Olena A. Sirenko \\ Institute of Geological Sciences of the National Academy of Sciences of Ukraine, Kyiv, Ukraine, o_sirenko@ukr.net
}

Received: 07.10.2019

Received in revised form: 20.10 .2019

Accepted: 06.11.2019

\begin{abstract}
The state of paleontological study of the Kuyalnik deposits of Odessa region, in particular the stratotype section near Kryzhanivka village was analyzed. Attention is paid to the absence of the palynological description of the Krizhanivka climatolith in the section and the insufficient palynological study of the liman-marine Kuyalnik sediments.
\end{abstract} The goal of the presented research was to obtain a detailed palynological description of the subaerial Eopleistocene and the limanmarine Kuyalnik sediments of the stratotype section near Kryzhanivka village. Based on the results of the research, the palynological description of rocks of the upper part of the section of the liman-marine Kuyalnik sediments is presented for the first time, as well as the materials to substantiate the correlation of the studied sediments with the Beregove and Siversk climatolyths of the continental Upper Cenozoic section of Ukraine, which correspond to the Gelasian of the International Stratigraphic Scale (ISS). For the first time, palynological description of the Kryzhanivka climatolith correlated with the Calabriane of the ISS is presented for the studied section. Three subcomplexes are described in the composition of the Kryzhanivka complex. The characteristic features of the Kryzhanivka spore-pollen complex (SPC) and the changes in the ecological structure of each subcomplex are determined. Correlation of the established complex with the even-aged SPC of the Kryzhanivka deposits of the southern part of the Ukrainian Shield (the Eastern Azov Sea region). Outstanding questions of stratigraphic division of different facial deposits of the section based on palynological data are outlined. The necessity of further palynological studies of deposits of the section near Kryzhanivka village is substantiated.

Keywords: Gelasian, Calabriane, continental deposits, liman-marine sediments, spore-pollen analysis, Ukraine.

\section{Палінологічні дані до характеристики аналогів гелазію та калабрію у стратотиповому розрізі куяльницьких відкладів біля с. Крижанівка (Одеська область)}

\section{О.А. Сіренко}

Інститут геологічних наук НАН Украӥни, Київ, Украӥна, о_sirenko@ukr.net

Анотація. Проведено аналіз стану палеонтологічної вивченості куяльницьких відкладів Одеського регіону, зокрема у стратотиповому розрізі біля с. Крижанівка. Акцентовано увагу на відсутності палінологічної характеристики крижанівського кліматоліту у розрізі та недостатню палінологічну вивченість лиманно-морських куяльницьких відкладів. Метою представленого дослідження було отримання детальної палінологічної характеристики субаеральних еоплейстоценових та лиманно морських куяльницьких відкладів стратотипового розрізу біля с. Крижанівка. За результатами проведених досліджень вперше наведено палінологічну характеристику порід верхньої частини розрізу лиманно-морських куяльницьких відкладів, а також представлено матеріали до обгрунтування кореляції досліджених відкладів з берегівським та сіверським кліматолітами континентального верхньокайнозойського розрізу України, які відповідають гелазію Міжнародної стратиграфічної шкали (МСШ). Вперше для вивченого розрізу наведено палінологічну характеристику крижанівського кліматоліту, що корелюється 3 калабрієм МСШ. У складі крижанівського комплексу описано три підкомплекси. Визначено характерні особливості крижанівського спорово-пилкового комплексу (СПК) та відміни екологічної структури кожного з підкомплексів. Проведено кореляцію встановленого комплексу з одновіковим СПК крижанівських відкладів південної частини Українського щита (Східне Приазов'я). Окреслено невирішені питання стратиграфічного розчленування різнофаціальних відкладів розрізу за палінологічними даними. Обгрунтовано необхідність проведення подальших палінологічних досліджень відкладів розрізу біля с. Крижанівка.

Ключові слова: гелазій, калабрій, континентальні відклади, лиманно-морські відклади, спорово-пилковий аналіз, Украӥна. 
Introduction. The Kuyalnik deposits of Odessa region have long been of considerable interest to research paleontologists, lithologists, and paleomagnetologists. The Kuyalnik deposits were first described by I.F. Sintsov (Sintsov, 1875) on the right bank of the Kuyalnik liman near Odessa. Later, based on the faunal data, I.F. Sintsov (Sintsov, 1897) dated the established deposits to the Upper Pliocene and divided them into two horizons: the Lower horizon with cardiidae and the Upper horizon with freshwater forms.

At the subsequent stages of the research, the paleontological description of the Kuyalnik deposits of Odessa region were significantly expanded and supplemented by T.A. Mangikian (Mangikian, 1929), I.Ya. Yatsko (Yatsko, 1954), V.N. Semenenko (Semenenko, 1987), and P.D. Frolov (Frolov, 2013) based on the study of mollusk fauna; V.G. Sheremeta (Semenenko, Sheremeta, 1963), G.I. Karmishina (Karmishina, 1973), K.N. Negadaev-Nikonov, A.V. Karelina, N.M. Ilnitskaya (Negodaev-Nikonov, Karelina, Ilnitskaya, 1977) with ostracode; I.M. Gromov and A.I. Shevchenko (Gromov, Shevchenko, 1961), A.S. Tesakov (Tesakov, 2002), Topachevsky V.A., Skorik A.F., Rekovets L.I (Topachevsky, Skorik, Rekovets, 1989) Krokhmal' A. I. (Krokhmal', 2009) with small mammals. Based on the fauna of freshwater mollusks, G.I. Popov compared the lower horizon of the Kuyalnik deposits of Odessa region with the Upper Akchagyl of Caspian region (Popov, 1962), and K.V.Nikiforova (Nikiforova, 1962) based on the fauna of vertebrates - with Villafranca of Western Europe. Subsequently, detailed correlation comparisons between the Kuyalnik deposits of Odessa region and the Akchagyl rocks of Caspian region for mollusk fauna were carried out by P.F. Gozhik (Gozhik, 2006, Gozhik, 2019) and A.L. Chepalyga (Chepalyga, 1992).

It should be noted that in spite of the well-studied Kuyalnik deposits of Odessa region, the age of the rocks in the section near Kryzhanivka village as well as their correlation with even-aged continental sediments is still the subject of discussion. Particularly, based on the study of ostracods, G.I.Karmishina (1973) concluded that the upper part of the section of the Kuyalnik deposits near Kryzhanivka village dates back to the Pleistocene. Unfortunately, magnetologists do not also have a single opinion on the paleomagnetic characteristics of the Kuyalnik deposits of the studied section. (Pevzner, 1989; Tretyak, 1967; Tretyak, Volok, 1974).

The section of subaerial deposits near Kryzhanivka village overlapping the Kuyalnik deposits is also of considerable interest since it is a stratotype of the Kryzhanivka pedohorizon (Veklich, 1982).

Unfortunately, the palynological characterization of the Kuyalnik deposits of the section under consideration is fragmentary. N.A. Shchekina (Shchekina, 1964) studied single samples from the lower section of the Kuyalnik deposits by spore-pollen analysis. Based on the obtained data, it was suggested that according to palynological data, the rocks of the upper part of the Kuyalnik deposit section of the North Azov Sea can be correlated with the deposits of the lower part of the section near Kryzhanivka village. The upper part of the liman-marine sediments has not been studied palynologically up to date.

Despite the fact that the section near Kryzhanivka village is a stratotype of the Kryzhanivka pedohorizon, palynological studies of rocks have not been conducted. S.I.Turlo reconstructed the vegetation of the Kryzhanivka time based on the study of the Kryzhanivka soils of the Azov, Middle Dnieper and Donets Basin sections (Sirenko, Turlo, 1986).

The author made an attempt to fill in this gap.

Materials and methods of research. The studied section is located within the coastal cliff of the Black Sea at the southeastern margin of Kryzhanivka village of Odessa region (Fig.1). The deposits of the studied

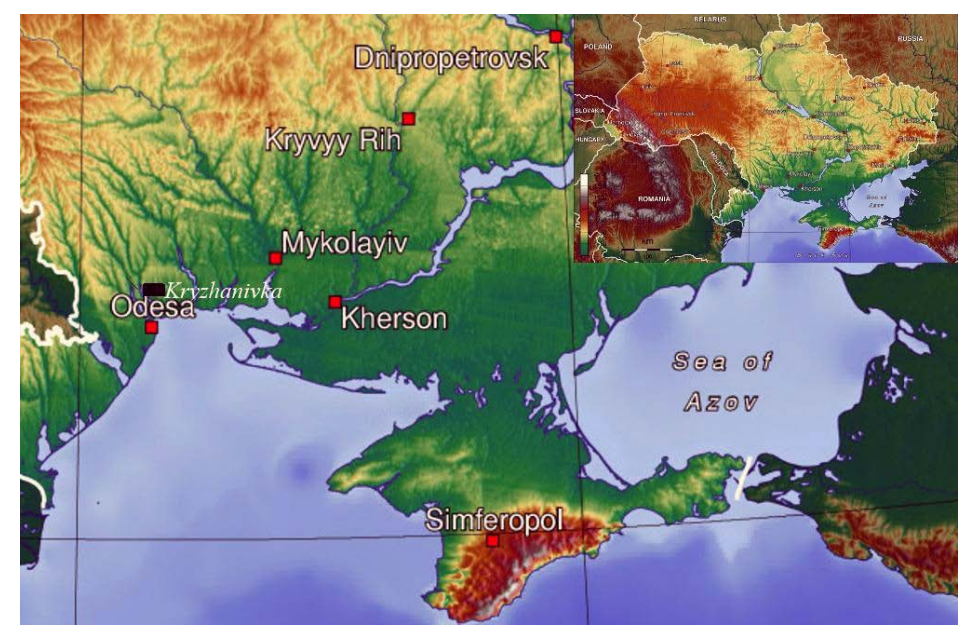

Fig. 1. The section location 


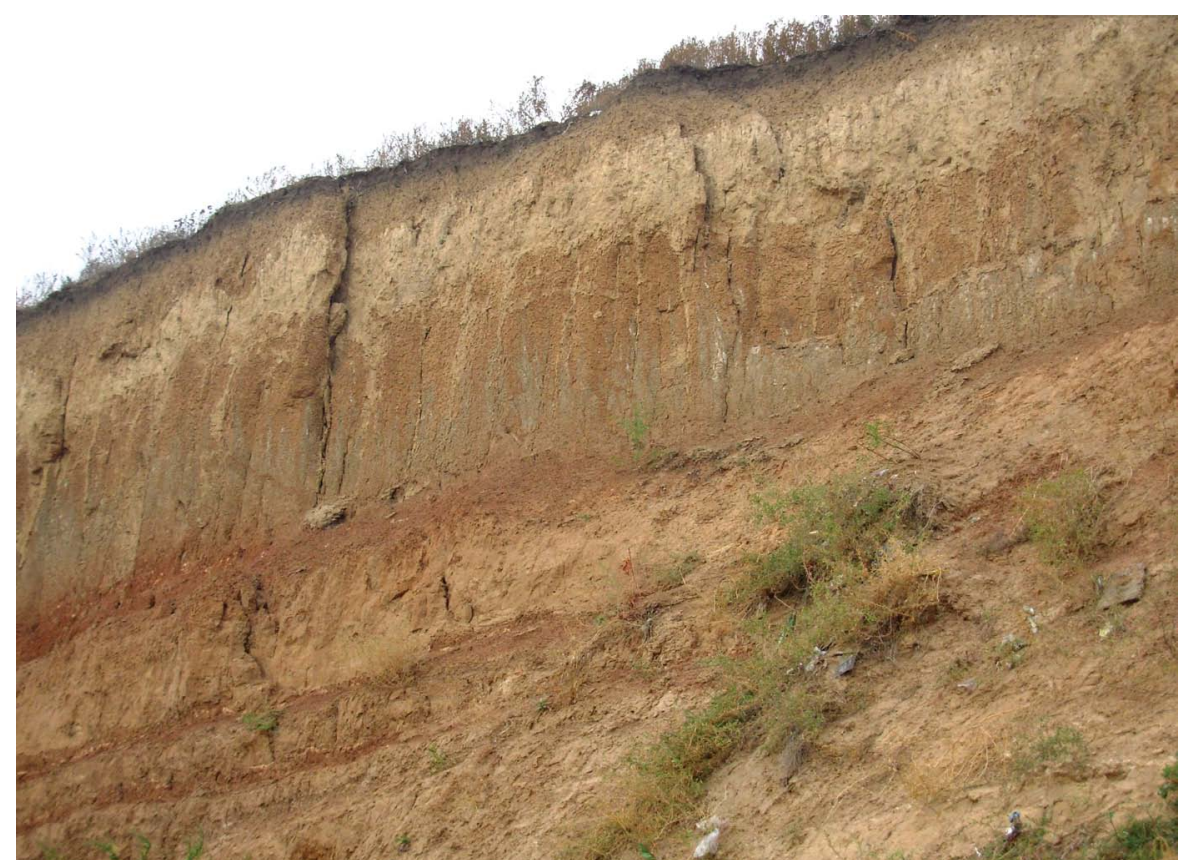

Fig. 2. General view of the outcrop uncovering the upper part of the section near Kryzhanivka village

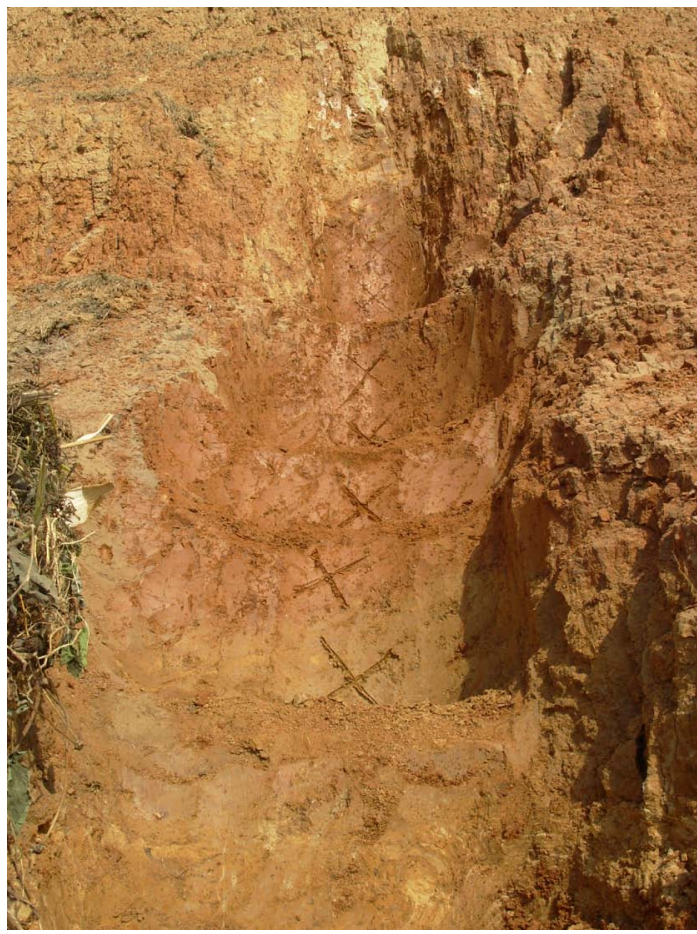

Fig. 2a. Clearance 1 - the Kryzhanivka pedohorizon

section were lithologically described repeatedly. The most detailed lithological description of the liman-marine rocks of the studied section is given in INQUA Guidebook edited by Nikiforova, 1982 while the subaerial Pleistocene deposits overlapping them is given in the monograph (Veklich, Sirenko, 1972). Taking into consideration all of the above, we will not give a detailed lithological description of the studied deposits. The section was studied in two outcrops (Fig. 2 and Fig. 3).

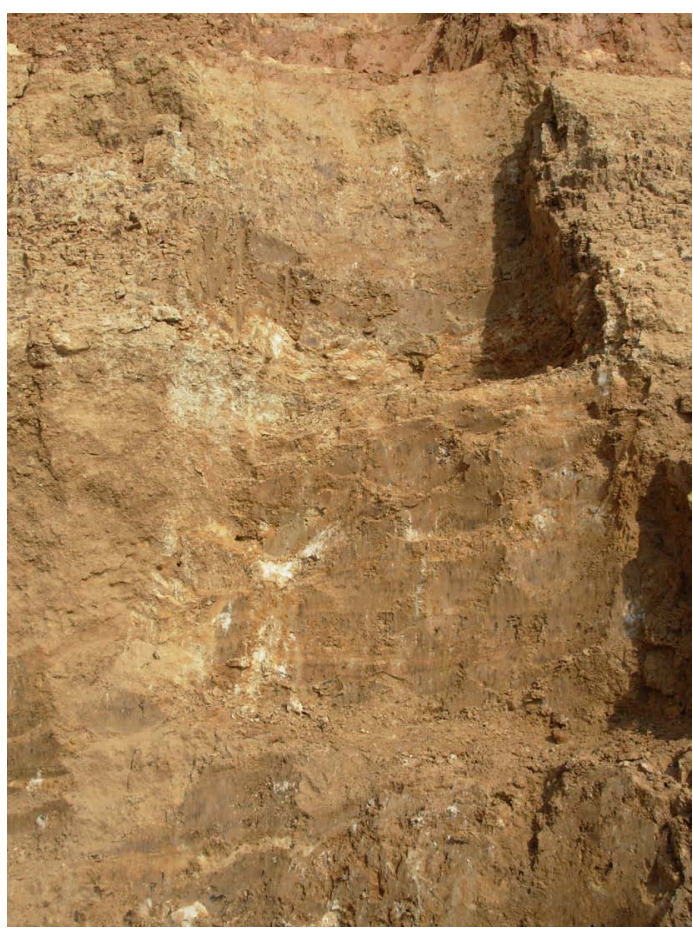

Fig.2b. Clearance 2 - the Berezan deposits underlying the Kryzhanivka pedohorizon and the upper part of the section of liman-marine sediments

Fig. 4 shows the lithological columns of deposits of the investigated section.

The first outcrop (Fig. 2) is located in the coastal cliff near the boat station. Studied rocks were uncovered by two clearances. The first clearance (Fig. 2a) revealed a pedohorizon consisting of three soils, which we previously dated to the Kryzhanivka, as well as heavily sandy loess-like clay underlying it. The red-colored soil is overlain by the Eopleistocene and Lower Neopleistocene deposits. The second 


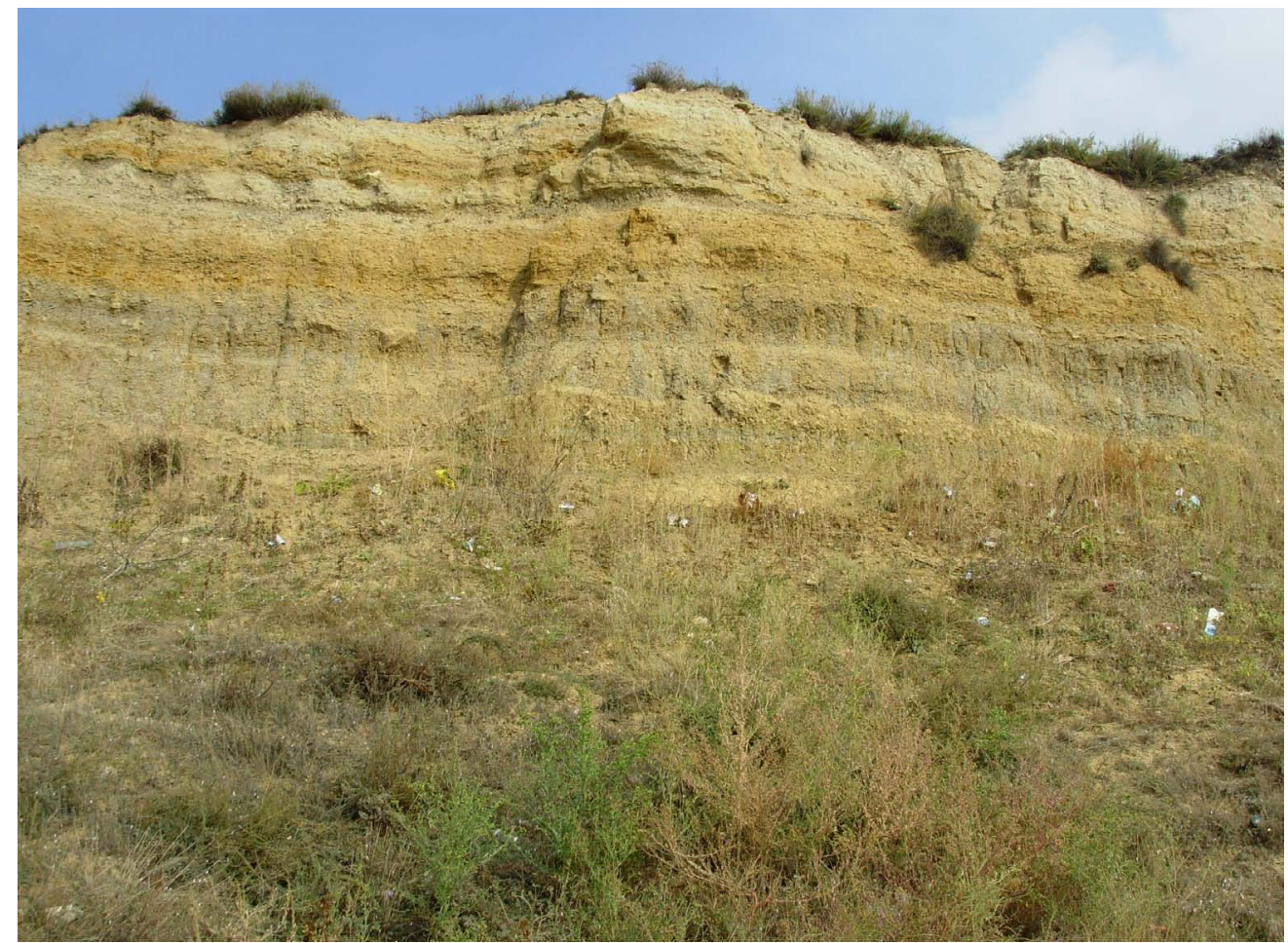

Fig.3. General view of the outcrop uncovering liman-marine sediments

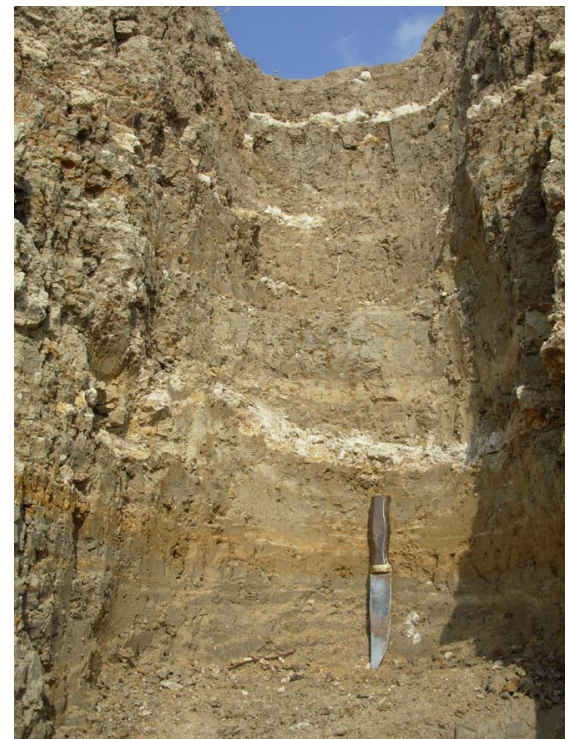

Fig 3a. Clearance 1 the upper part of the section

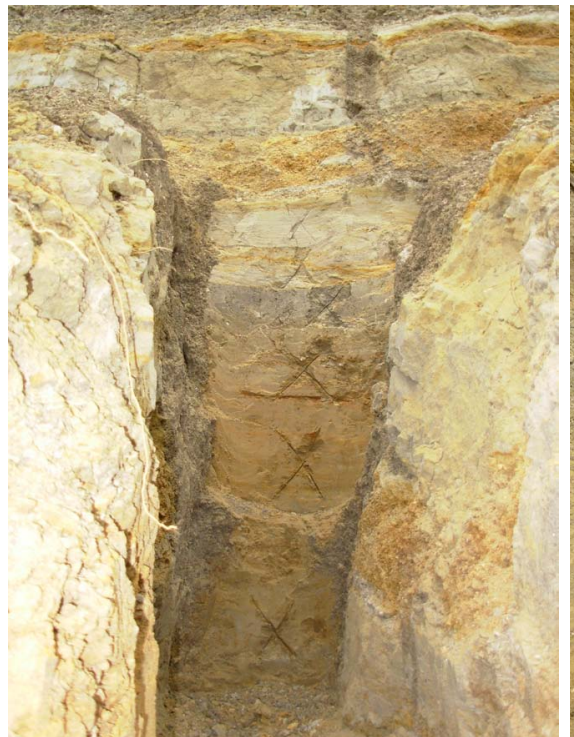

Fig 3b. Clearance 2 the middle part of the section

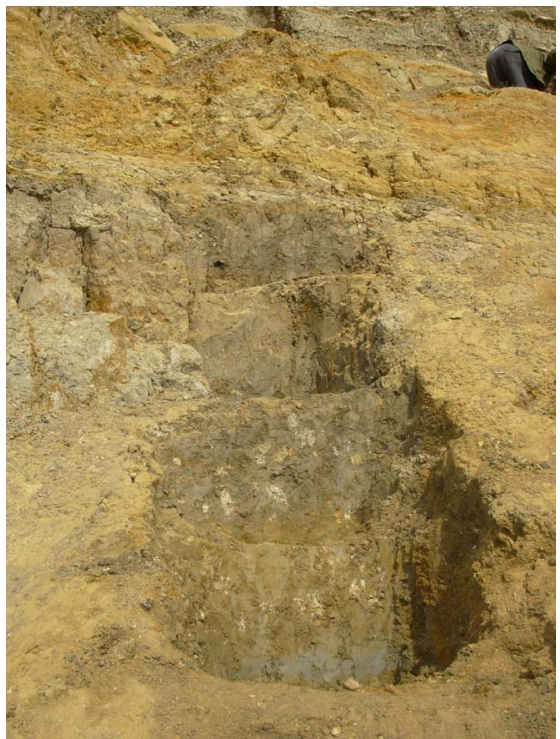

Fig. 3c. Clearance 3 the bottom of the section clearance (Fig. 2b) revealed clay traced at the bottom of the red-colored Kryzhanivka pedohorizon, which is strongly sandy, thinly laminated with thin layers of red-colored fossil soils, between which there is a sand lens. The liman-marine deposits lie below.

The second outcrop (Fig. 3) is located on the coastal cliff on the left side of the ravine on the southeastern outskirts of Kryzhanivka village. Deposits were investigated by three clearances. The first one (Fig. 3a) revealed the uppermost part of the liman-marine sediment section represented by gray dense clays with tiled carbonate nodule lenses, which apparently extends the gray clay section revealed in the lower part of the second clearing of the first outcrop. The second clearance (Fig. 3b) revealed the middle part of the section: shell rocks, sand interlayers with pebbles, as well as gray, light gray and light brown heavily sandy clays with a pronounced lamination in some places. The third clearance (Fig. 3c) revealed the lowest part of the section represented by gray and brownish-gray clays with carbonate nodules.

Main results. The palynological description of the studied deposits is presented (bottom-up). Unfortunately, the clay revealed by the third 


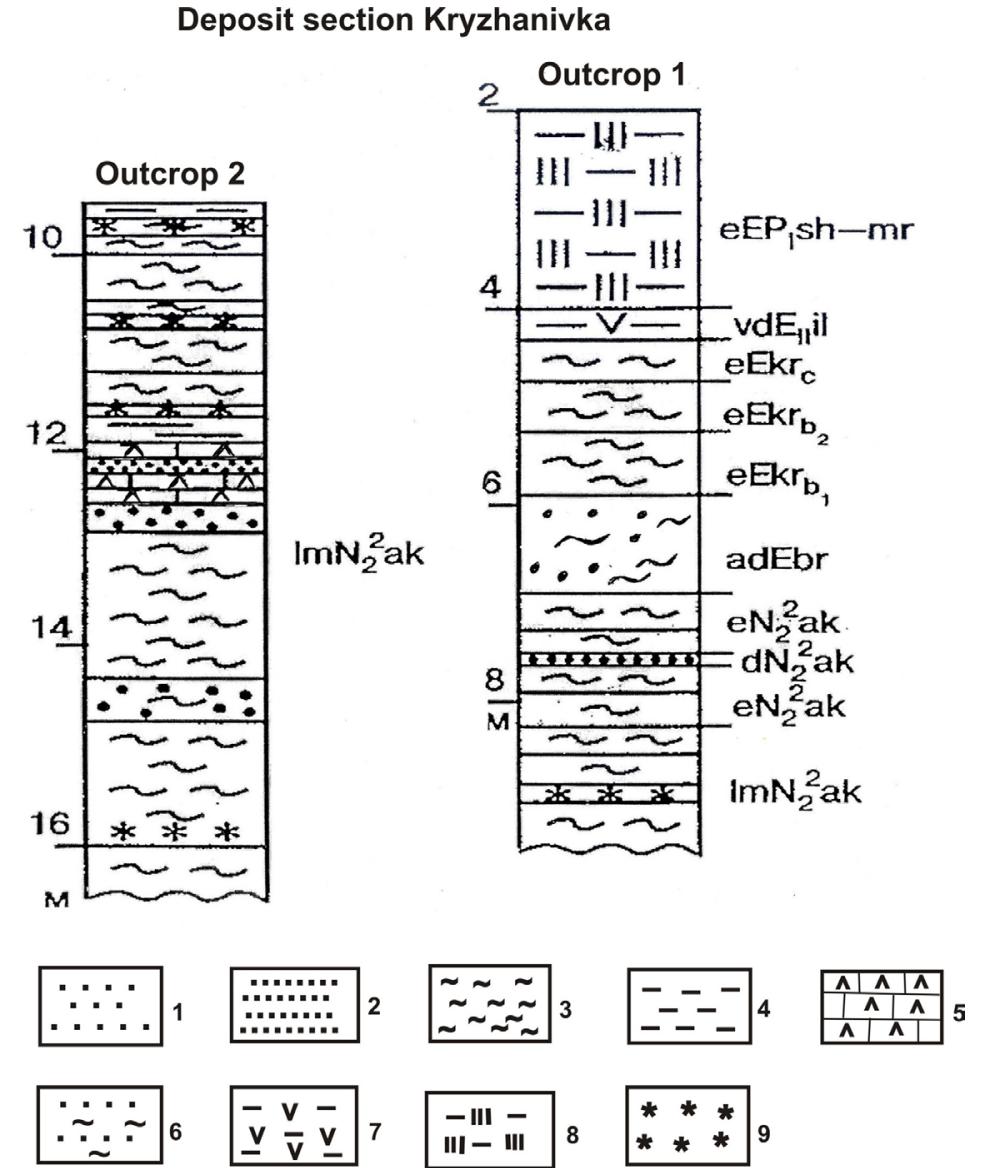

Fig. 4. Studied outcrops of the section near Kryzhanivka village

1 - sands, 2. - sandstones,3. - clay 4. - mudstones, 5. - shell rock; 6-clay sands;

7. - loamy loams 8. - heavy loams 9. - phosphate rock

clearance of the second outcrop (Fig. 3c) did not allow obtaining representative materials to establish spore-pollen complexes (SPC). The following were distinguished from the rocks of the uppermost part of the stratum: pollen grains of Pinus subg. Diploxylon Koehne. (prevail), single Pinus sp. sect. Cembrae Spach., pollen in small amounts: Alnus spp., Betula spp., Carpinus cf. betulus L., Tilia cf. cordata Mill., Tilia sp., Comptonia sp., Juglans cf. regia L. Pollen grains of herbaceous plants belong to Poaceae, Chenopodiaceae, Asteraceae, and Sparganium sp.

The rocks revealed by the second clearance were more informative (Fig. 3b). According to the results of palynological studies of light brown clays (a range of 12.0-13.0 m), which were traced in the middle part of the stratum uncovered by this clearance, a SPC was established. Its composition consisted of an approximately equal amount of the pollen of wood species (53.4-55.9\%) and herbaceous plants (47.6$44.1 \%$ ). In the group of wood species, Pinus pollen grains mainly belonging to Pinus subg. Diploxylon Koehne. predominate (42.0-42.3\%), and the content of Pinus sp. sect. Cembrae Spach. pollen does not exceed $2.4 \%$. Single pollen of Picea sect. Omorica Willkm. is observed. In the group of deciduous plants (11.4-12.7\%), pollen of plants of the moderate-warm zone (6.7-7.3\%) prevails: Quercus cf. pubescens Willd., Q cf. robur L., Quercus sp. (in the amount of 3.8-4.6\%); pollen grains of Tilia $\mathrm{cf}$. cordata Mill., Tilia $\mathrm{sp}$. (in the amount of 2.9-1.8\%) were also found, and single Corylus cf. cornuta Marsh. Thermophilic plants (up to $1.9 \%$ ) are represented by pollen of Juglans cf. regia L. and $J$. cf. cinerea L. In the group of smallleaved plants of the temperate zone (2.8-3.6\%), Alnus cf. incana (L.) Moench., Alnus sp., Betula sp. sect. Albae were established.

Herbaceous plant pollen is $47.6-44.1 \%$ and mainly refers to Chenopodiaceae (30.4-27.7\%). Pollen grains of Poaceae (2.9-3.7\%), Asteraceae (6.7-5.5\%) and miscellaneous herbs (6.7-5.4\%): Polygonaceae, Lamiaceae, Ranunculaceae, Rosaceae occurred in smaller amounts. Small dwarf shrubs are represented by single pollen of Ephedra sp. The taxonomic composition of the established SPC as well as a high content of herbaceous plant pollen in its composition belonging mainly to Chenopodiaceae 
family approaches it to the complexes of the middle part of the Kuyalnik deposit section of the Azov Sea as well as their continental analogues - the Siversk deposits of the Platform Ukraine.

Taking into consideration the incompleteness of the obtained palynological materials (representative data on the results of studies of rocks revealed by the third clearance were not obtained) as well as the fact that not all the layers revealed in this clearance were palynologically characterized, we cannot determine for the present which part of the section of the Middle
In the composition of the first subcomplex (a range of 12.0-11.6 m), wood species pollen reaches $70.0-71.7 \%$. In this group, the pollen grains of Pinus (57.6-60.4\%), related mainly to Pinus subg. Diploxylon Koehne. subgenus, predominate. At the same time, the amount of Pinus subg. Haploxylon Koehne. pollen increased up to $5 \%$ in comparison with the previous complex. The content of pollen of thermophilic plants such as Juglans cf. regia L., J. cf. cinerea L., Pterocarya sp. increased up to $2.9 \%$. The amount of pollen of deciduous species of the

Table 1.The pollen composition of plants of moderate-warm, warm- moderate zones and thermophilic plants in the spore-pollen complex from Beregove pedogorizon of the sections near the villages of Kulikovske and Kryzhanivka

\begin{tabular}{|c|c|c|}
\hline $\begin{array}{l}\text { Spore-pollen } \\
\text { complex }\end{array}$ & section Kulikovske & section Kryzhanivka \\
\hline \multirow{18}{*}{ 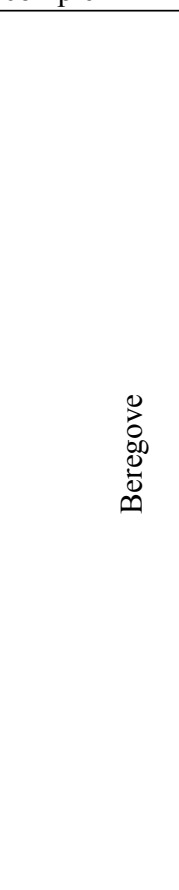 } & Juglans cf. cinerea L. & Juglans cf. cinerea $\mathrm{L}$. \\
\hline & J. nigra L. & J. cf. regia L. \\
\hline & Pterocarya $\mathrm{sp}$ & Pterocarya sp. \\
\hline & Carpinus cf. betulus L. & Carpinus sp. \\
\hline & Fagus cf. sylvatica L. & Fagus cf. sylvatica L. \\
\hline & F. cf. taurica L. & F. cf. orientalis Lipsky., \\
\hline & Quercus cf. robur L. & Quercus cf. robur L. \\
\hline & Q. pubescens Willd. & Q. pubescens Willd. \\
\hline & Q. cf. petrae L. & Quercus sp. \\
\hline & Tilia cf. cordata Mill. & Tilia cf. cordata Mill. \\
\hline & T. cf. platyphyllos Scop. & T. cf. platyphyllos S cop. \\
\hline & Tilia. $\mathrm{sp}$. & Tilia $\mathrm{sp}$. \\
\hline & Zelkova sp. & - \\
\hline & Rhus sp. & - \\
\hline & Nyssa sp. & - \\
\hline & Corylus sp. & Corylus sp. \\
\hline & Myrica sp. & Myrica sp. \\
\hline & Moraceae & Moraceae \\
\hline
\end{tabular}

Kuyalnyk (Siversk) deposits includes the studied rocks. The participation of thermophilic plant pollen is typical for the spore-pollen spectra characterizing the Intra-Siversk fossil soils. Thus, it can be assumed that the established complex characterizes deposits correlated with the Middle Siversk, however, this conclusion is preliminary.

We obtained more complete palynomaterials when studying the upper part of the section of the second outcrop revealed by the first clearance (Fig. 3a).

Based on the results of the studies, a SPC is described, in which two subcomplexes are traced. A characteristic feature of the established complex is the dominance of wood species in pollen spectra as well as the increased pollen content of Pinus sp. subg. Haploxylon Koehne. and thermophilic plants in comparison with the previous SPC. temperate and moderate-warm zones practically remained at the level of the previous SPC, however, its taxonomic composition expanded and was replenished with the representatives of the warmmoderate zone. In addition to the taxa established in the previous SPC, pollen of $T$. cf. platyphyllos Scop., Carpinus sp., Myrica sp., and the group of shrubs - Tamaricaceae and Thymelaeaceae appeared. Pollen of deciduous plants of the temperate zone is not numerous (0.9-1.9\%) and belongs to Betula sp. Dwarf shrubs are represented by single pollen grains of Ephedra sp.

In contrast to the previous SPC, the amount of herbaceous plant pollen markedly decreased (29.126.4\%). The dominants also changed in this group. The dominant position was taken by Artemisia spp. pollen $(10.7-9.5 \%)$ and other representatives of Asteraceae 
family (6.8-6.6\%). The amount of Chenopodiaceae pollen decreased to $4.9-3.8 \%$. The content of Poaceae pollen does not exceed $1.9 \%$. Miscellaneous herbs are represented by Caryophyllaceae, Polygonaceae and Ranunculaceae. Spores of Sphagnum sp. and Bryales appeared.
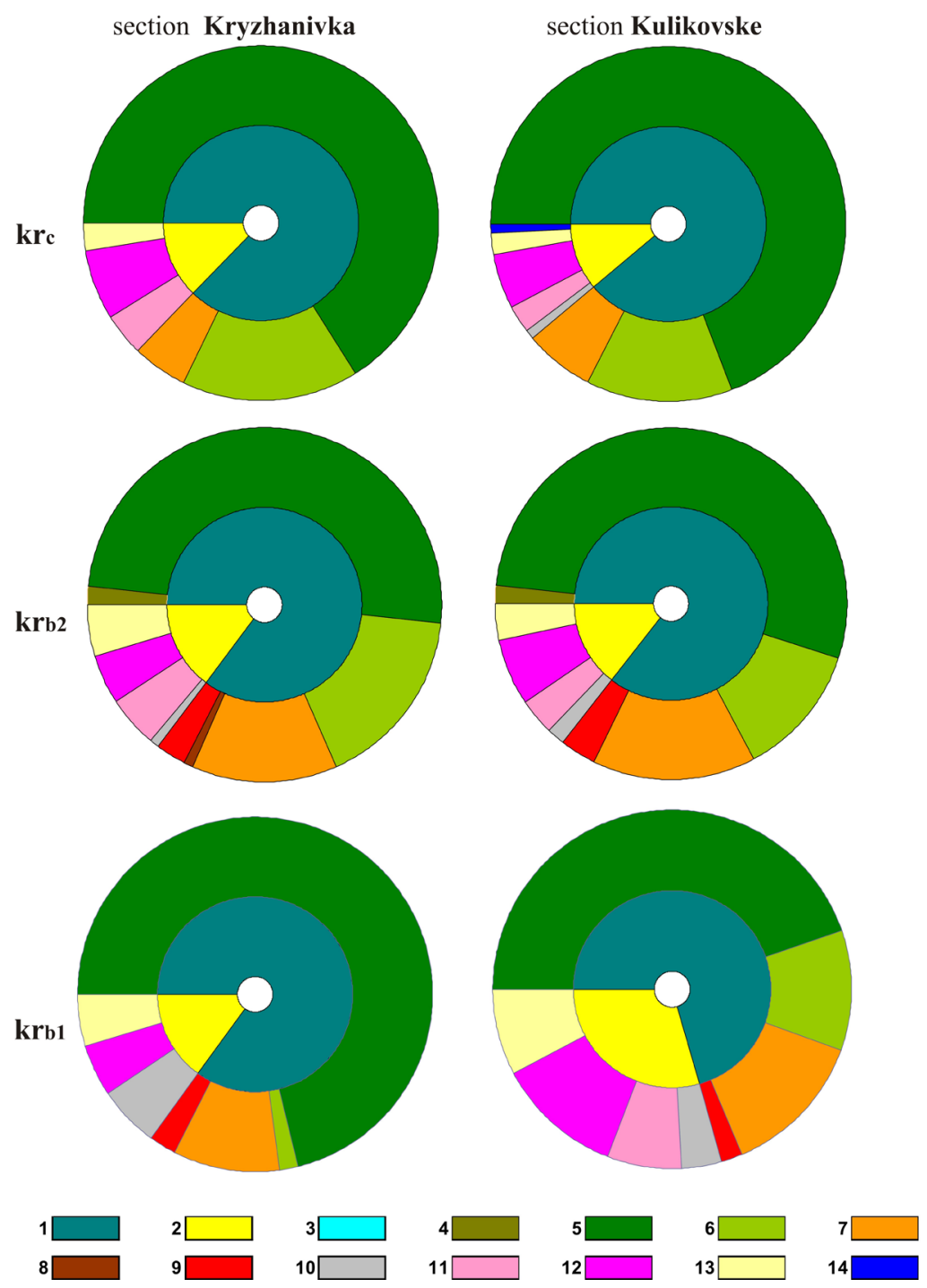

Fig 5. Ecological structure of spore-pollen complexes of the Kryzhanivka deposit sections near Kryzhanivka village (the Black Sea Depression) and Kulikovske village (the southern part of the Ukrainian Shield).

\author{
$1-$ pollen of wood species \\ 2- herbaceous plants \\ 3- spores \\ 4- Picea \\ 5- Pinus \\ 6- deciduous plants of the temperate zone \\ 7-deciduous plants of the moderate-warm zone
}

pollen in the moderate-warm zone (11.7-9.3\%) as well as thermophilic plants (6.9-5.7\%), an increase in the content of Pinus sp. sect. Strobus Schaw. and $P$. sp. sect. Cembrae Spach. pollen (in the amount up to $8.1 \%$ ), and the appearance of Picea sp. sect. Eupicea Willkm. pollen grains. Among the deciduous plants, 
deciduous plants of the temperate zone is in the range from 2.8 to $3.6 \%$.

In comparison with the first subcomplex, the role of herbaceous plant pollen decreased still more (19.1-16.2\%), especially due to pollen grains of Artemisia spp. (4.8-2.9\%) and Asteraceae (1.9$3.8 \%$ ). The content of Chenopodiaceae pollen remained at the level of the previous subcomplex. The amount of miscellaneous herb pollen did not change in comparison with the first subcomplex, but only its taxonomic composition somewhat expanded including Ranunculaceae, Primulaceae, Polygonacea, and Urticaceae. Dwarf shrubs are represented by single pollen grains of Ephedra sp.

Analogs of the established complex among the SPC of the marine sediments of the Azov Sea were not ascertained. The dominance of wood species in the pollen spectra including the high content and taxonomic diversity of broad-leaved species pollen of the moderate-warm zone and thermophilic plants approaches the described complex to the SPC characterizing the coastal sediments of the section near Kulikovske village (the Eastern Azov region) (Tab. 1.). However, this comparison also requires further confirmation since at this stage of the research we were not able to isolate pollen and spores from rocks exposed by the second clearance (Fig. 2b) of the first outcrop traced at the bottom of the red-colored Kryzhanivka pedohorizon, which is strongly sandy, thinly laminated with thin layers of red-colored fossil soils.

It should be noted that the studied deposits were apparently formed in shallow conditions as evidenced by a significantly higher percentage of Pinus pollen in the composition of the spectra as well as a low pollen concentration in macerates. According to E.Z. Isagulova (Isagulova, 1974) precisely for the spectra of the deposits of the shallow part of the basin, a highest amount of pine pollen is typical. According to the materials of E.S. Malyasova (Malyasova, 1986), the lowest concentration of spores and pollen was recorded in the samples taken on the coastal strip.

Thus, the presented palynological data as well as the lithological composition of the studied sediments indicate that the rocks of the studied section were formed under slightly different conditions as compared with those of the East Azov Sea. Because of the fact that most of the sediments of the studied section were formed mainly in shallow water, the established SPC are already close in composition to complexes of the continental Pliocene deposits.

Representative palynospectra are established of a red-colored pedohorizon in a range from 5.9 to 4.5 m (Fig. 2a). Two soils of early and late optimums of pedogenesis are clearly traced in the composition of the pedohorizon. The soil of early optimum (a range from 5.9 to $5.25 \mathrm{~m}$ ) is reddish-brown with a distinct reddish tinge, the brightest in color, and has a fine-lumpy structure impregnated with $\mathrm{Mn}$. The soil of late optimum (a range from 5.25 to $4.7 \mathrm{~m}$ ) is reddish-brown, dense, argillic, and has a comminuted-prismatic structure with shiny structural elements, films and spots of manganese without visible carbonates. In the range from 4.7 to $4.5 \mathrm{~m}$, a brown soil interlayer with a reddish tint, and a less dense structure than an underlying soil was traced. A spore-pollen spectrum characterizing the indicated interlayer is typical for spectra corresponding to soils of the final pedogenesis stage. Three subcomplexes are clearly traced in the complex characterizing the described pedohorizon. A common feature of all the SPC subcomplexes is the dominance of wood species pollen in their composition; however, they differ in the ecological structure.

As a part of the first subcomplex characterizing the lowest soil of the pedohorizon (a range of 5.9$5.25 \mathrm{~m}$ ), wood species pollen is $84.9-85.4 \%$. The dominant role in this group belongs to the pollen grains of Pinus (71.0-72.9\%), which mainly refer to Diploxylon subgenus species with the participation of Haploxylon subgenus representatives (7.2-6.4\%). In the group of deciduous plants (12.9-15.3\%), pollen of moderate-warm zone plants dominates (8.8-10.6\%): Quercus spp., Tilia ef. cordata Mill., T. cf. dasystyla Stev., Tilia cf. tomentosa Moenh. In comparison with the previous SPC, the amount of thermophilic plant pollen decreased to 2.4-3.7\%: Juglans cf. cinerea L., Moraceae. Deciduous plant pollen of the temperate zone is small (0.9-1.6\%) and belongs to Betula spp. Herbaceous plant pollen is also not numerous (13.6$14.6 \%$ ). Poaceae pollen grains dominate in this group (4.0-6.1\%). Miscellaneous herb pollen: Apiaceae, Polygonaceae, Cannabaceae, Ranunculaceae, and Rosaceae acts as a subdominant (4.0-4.8\%). Asteraceae (1.8-2.4\%) and Artemisia spp. pollen grains occurred in smaller amounts $(0.9-1.6 \%)$.

In the spectra of the second subcomplex characterizing the second optimal soil of the pedohorizon (a range of 5.25-4.7 m), wood species pollen also dominates (85.6-84.2\%). However, in comparison with the first subcomplex, the role of deciduous species pollen significantly increased (up to $30.7-33.1 \%$ ), which mainly belongs to smallleaved plants of the temperate zone (15.2-18.7\%): Betula spp. (11.2-13.9\%), Alnus spp. (2.4-3.9\%), and Salix sp. (0.9-1.6\%). The dominants in the group of 
broad-leaved species of the moderate-warm zone remained at the level of the first subcomplex, and only the amount and species diversity of Tilia pollen: Tilia cf. cordata Mill. and T. cf. dasystyla Stev. decreased (2.9-3.2\%). In addition, pollen grains of Fagus sp. singly occurred as well as Myrica sp. of the moderatewarm plant group. Corylus spp. pollen also appeared (2.9-1.6\%). In comparison with the first subcomplex, the role of Pinus spp. pollen significantly decreased (49.7-50.2\%) although its species did not change, and Picea sp. pollen grains (0.9-1.6\%) appeared. In the group of herbaceous plant pollen (15.2-15.8\%), as compared with the first subcomplex, a change in dominants occurred, notably Chenopodiaceae (4.0$4.9 \%)$ and Artemisia sp. (4.0-4.9\%) pollen grains prevailed. The amount of miscellaneous herb pollen remained at the level of the previous subcomplex.

In the composition of the third subcomplex corresponding to the soil of the final stage of pedogenesis (a range of 4.7-4.5 $\mathrm{m}$ ), the highest content of wood species pollen (87.2\%), which belongs mainly to Pinus spp., occurred. Picea pollen was not found. A number of deciduous plants decreased to $19.0 \%$ as compared with the second subcomplex. Betula spp. pollen (15.8\%) dominates in this group. Among the deciduous plants of the moderate-warm zone, pollen grains of Quercus cf. robur L. (2.4\%), and single Tilia cf. cordata Mill. and Corylus cf. avellana L. occurred. Dominants in the group of herbaceous plants (12.8\%) did not change in comparison with the second subcomplex, only the role $(2.4 \%)$ and taxonomic diversity of miscellaneous herb pollen decreased.

According to the taxonomic composition of pollen, the established SPC is close to the Kryzhanivka deposit complex of the section near Kulikovske village (the southern region of the Ukrainian Shield, the Eastern Azov region), (Sirenko, 2017). The compared SPCs are united by the presence of Picea pollen in the subcomplexes of the middle part of the pedohorizon and the growing role of small-leaved plant pollen from the first subcomplex to the second one (Fig. 5). These patterns are indicative of the Kryzhanivka SPC of most sections of the Plain Ukraine.

The individual features of the established SPCs specified by the location of the section in the coastal zone include a markedly high content of Pinus pollen in the spectra, which is always typical for the complexes of sea coast sediments. We noted the same feature for the SPC of the Pliocene and Eopleistocene deposits of the section near Kulikovske village.

Conclusion. The conducted studies enabled to perform a palynological characterization of rocks of the upper part of the Kuyalnik deposit section near Kryzhanivka village as well as obtain arguments in favor of the correlation of the studied sediments with the Beregove and Siversk climatoliths of the continental section. However, this conclusion still requires further confirmation. Previously, according to the palynological data (Sirenko, 2017), it was found that of the Beregove and Siversk climatolith deposits of the continental Upper Cenozoic section of Ukraine correspond to the Gelasian of the International Stratigraphic Scale (ISS). According to the decision of the International Union of Geological Sciences to drop the lower boundary of the quarter to a level of 2.58 million years, the ISS Gelasian deposits are already attributed to the Pleistocene. Consequently, the upper part of the Kuyalnik deposit section in the studied section can be dated by the Pleistocene.

According to the stratigraphic scheme of the Quaternary deposits of Ukraine (the Stratigraphic Code, 2012), the Kryzhanivka pedohorizon refers to the Eopleistocene and correlates with the Calabriane in the ISS. The conducted studies provided to obtain the detailed palynological characteristics of Odessa region for the first time as well as correlate it with coeval deposits of the Azov Sea region.

Palynological studies of subaerial and limanmarine sediments of the section near Kryzhanivka village must be continued in the future in order to obtain a more detailed description of all the traced horizons of different-facies deposits.

\section{References}

Chepalyga, A.L., 1992. Paleogeografiya i paleoekologiya bassejnov Chernogo i Kaspijskogo morej (PontoKaspiya) v plejstocene. [Paleogeography and paleoecology of the basins of the Black and Caspian seas (Ponto-Caspian) in the Pleistocene:]. abstract of a dissertation for the degree of Doctor of Geographical Sciences, specialty 11.00.04 "Geomorphology and paleogeography" Moscow, 40. (in Russian).

Frolov, P. D., 2013. Stratigraficheskoe, paleoekologicheskoe i paleoklimaticheskoe znachenie presnovodnyh i solonovatovodnyh mollyuskov yuga Vostochnoj Evropy [Stratigraphical, paleoecological, and paleoclimatical significance of freshwater and brackish mollusks of southern Eastern Europe]. dissertation abstract for the degree of candidate of geological and mineralogical sciences: special. 25.00.02 "Paleontology and stratigraphy" Moscow, 23. (in Russian).

Gozhik, P.F., 2006. Presnovodnye mollyuski pozdnego kajnozoya yuga Vostochnoj Evropy [Freshwater 
mollusks of the late Cenozoic south of Eastern Europe]. Part 1.«Geografika». Kyiv, (in Russian).

Gozhik, P.F., 2019. On the lower boundary of the Quaternary System in the Azov-Black Sea Basin Journal of Geology, Geography and Geoecology 28 (2), 292-300 doi: 10.15421/111929

Gromov I.M., Shevchenko A.I.,. 1961.Tushkanchiki (Rodentia, Dipodidae) iz kuyal'nickih otlozhenij yuga Ukrainy [Jerboa (Rodentia, Dipodidae) from Kuyalnyk deposits of the south of Ukraine]. Reports USSR Academy of Sciences 139, №.4, 976-979. (in Russian).

Isagulova, E.Z., 1974. Raspredelenie spor i pyl'cy v sovremennyh donnyh osadkah vostochnoj chasti Azovskogo morya. Marinopalinolinologicheskie issledovaniya v SSSR. [Distribution of spores and pollen in modern bottom sediments of the eastern part of the Sea of Azov]. Marinopalynological studies in the USSR - Nauka, Moscow 110-116. (in Russian).

Karmishina, G.I., 1973. K voprosu o vozraste otlozhenij stratotipicheskogo razreza kuyal'nika u s. Kryzhanovki v okrestnostyah g. Odessy [To the question of the age of deposits of the stratotypical section of the Kuyalnik near the village of Kryzhanovka in the vicinity of Odessa] Bulletin Moscow Society of Naturalists. Sep. Geol. 48, issue 4. 52-58. (in Russian).

Krokhmal', A.I., 2009. Biostratigraficheskoe raschlenenie eoplejstocenovyh otlozhenij central'noj chasti Severnogo Prichernomor'ya. [Eopleistocene sediments biostratification of central part of the northern Black sea coastel.] Collection of scientific works of the IGN NAS of Ukraine. Vol.2. 194-199 (in Russian).

Malyasova, E.S., 1976. Palinologiya donnyh osadkov Belogo morya [Palinology of bottom sediments of the White Sea].LGU, Leningrad 119 (in Russian).

Mangikian, T.A., 1929. O kuyal'nickih otlozheniyah okrestnostej Odessy [About the Kuyalnik deposits of Odessa region] Visn of Ukrainian Admin Geological Direction 14, 161-192 (in Russian).

Negadaev-Nikonov, K.N., Karelina, A.V, Ilnitskaya, N.M., 1977. Kompleksy ostrakod stratotipa kuyal'nika u s. Kryzhanovka (okrestnosti g.Odessy) [Complexes of ostracods of the Kuyalnik stratotype near the village of. Kryzhanovka (the outskirts of the city of Odessa)] Faunistic complexes and Cenozoic flora of the Black Sea coast. Academy of Sciences of the MSSR, Shtiintsa, Kishinev 80-84 (in Russian).

Nikiforova, K.V., 1962. O stratigraficheskom polozhenii kuyal'nickih otlozhenij [About the stratigraphic position of Kuyalnik deposits] Proceedings of the commission for the study of the Quarter period 20, 176-179 (in Russian).

Pevzner, M.A., 1989. Paleomagnitnaya harakteristika otlozhenij kuyal'nika i ego polozhenie v magnitohronologicheskoj shkale [Paleomagnetic char- acteristics of the deposits of the Kuyalnik and its position in the magnetochronological scale] Bulletin of the Commission for the Study of the Quaternary, № 58. 117-124 (in Russian).

Popov, G.I., 1962. O sootnoshenii kontinental'nyh i morskih verhnepliocenovyh otlozhenij yuga i yugovostoka Evropejskoj chasti SSSR v svyazi s voprosom o nizhnej granice chetvertichnogo perioda [About the ratio of continental and marine Upper Pliocene sediments of the south and southeast of the European part of the USSR in connection with the question of the lower boundary of the Quaternary] Bulletin of the Commission for the Study of the Quaternary 20, 92-97 (in Russian).

Semenenko, V.N., 1987. Stratigraficheskaya korrelyaciya verhnego miocena-pliocena Vostochnogo Paratetisa i Tetisa [Stratigraphic correlation of the Upper Miocene-Pliocene of East Paratethys and Tethys] Naukova Dumka, Kyiv (in Russian).

Semenenko, V.N., Sheremeta, V.G., 1963. Novye dannye o vremeni obrazovaniya pliocenovyh otlozhenij na yuge Ukrainy [New data about the time of formation of Pliocene deposits in the south of Ukraine] Geological journal 23(5), 80-85 (in Russian).

Shchekina, N.A., 1964. Rezul'taty sporovo-pyl'cevyh issledovanij kimmerijskih i kuyal'nickih otlozhenij yuga Ukrainy Nauchno-tekhnich. konferenciya po geologii i genezisu kimmerijskih zheleznyh rud Azovo-chernomorskoj rudnoj provincii. [The results of spore-pollen studies of the Cimmerian and Kuyalnytsky deposits of the south of Ukraine] Scientific and technical. conference of the geology and genesis of the Cimmerian iron ores of the Azov-Black Sea ore province]. Naukova Dumka, Kyiv 19-22 (in Russian).

Sintsov, I.F., 1875. Otchet o geologicheskih issledovaniyah V Bessarabii v 1873g. [Report on geological exploration in Bessarabia in 1873]. Notes of the Novorossiysk Society of Naturalists № 3. Vol. 1, 31-46 (in Russian).

Sintsov, I.F., 1897. O paleontologicheskom otnoshenii novorossijskih neogenovyh osadkov $\mathrm{k}$ plastam Avstro-Vengrii i Rumynii. [About of the paleontological relation of the Neogene Novorossian sediments to sediments of the Austrian-Hungary and Romania]. Memoires Novorossian Society of Naturalists. Vol. 21, iss 2, 88-125 (in Russian).

Sirenko, O.A., 2017 Palinostratigrafiya kontinental`nyh verhnepliocenovyh-nizhneneoplejstocenovyh otlozhenij yuzhnoj chasti Vostochno-Evropejskoj platformy [Palynostratigraphy of Continental Upper Pliocene - Lower Neopleistocene Deposits of Southern Part of the East European Platform] Naukova dumka, Kyiv (in Russian)

Sirenko, N.A., Turlo S.I., 1986. Razvitie pochv i rastitel'nosti Ukrainy $\mathrm{V}$ pliotsene i pleystotsene [The development of soil and vegetation of 
Ukraine in the Pliocene and Pleistocene]. Naukova dumka, Kyiv (in Russian).

Stratygrafichnyj kodeks Ukrai'ny 2012. Redaktor P.F. Gozhyk [Stratigraphic Code of Ukarine, P.F. Gozhyk (Editor-in-Chief)]. Kyiv (in Ukrainian).

Tesakov, A.S., 2004. Biostratigrafiya srednego pliocena - eoplejstocena yuga Vostochnoj Evropy (po melkim mlekopitayushchim). [Biostratigraphy of the Middle Pliocene - Eopleistocene of the south of Eastern Europe (for small mammals)] Nauka, Moscow (in Russian).

Topachevsky, V.A., Skorik, A.F., Rekovets, L.I., 1989. Gryzuny verhneneogenovyh i ranneantropogenovyh otlozhenij Hadzhibejskogo limana. [Rodents of the Upper Neogene and Early Anthropogenic sediments of the Hadzhibey estuary]. Naukova Dumka, Kyiv (in Russian).

Tretyak, A.N., 1967. Paleomagnetizm pozdnetretichnyh i chetvertichnyhotlozhenijUSSR. [Paleomagnetism of the Late Tertiary and Quaternary sediments of the Ukrainian SSR] Geophysics collection. Vol. 21. Naukova Dumka, Kyiv 73-81 (in Russian).
Tretyak, A.N., Volok, Z.I., 1967. Opyt paleomagnitnoj stratifikacii pliocen-chetvertichnyh otlozhenij na territorii USSR. [The experience of paleomagnetic stratification of Pliocene-Quaternary sediments in the territory of the Ukrainian SSR] Geophysics collection. Vol. 54. Naukova Dumka, Kyiv 50-55 (in Russian).

Veklich, M.F., 1982. Paleoetapnost' i stratotipy pochvennyh formacij verhnego kajnozoya. [The paleostages and stratotypes of soil formation of the Upper Cenozoic]. Naukova Dumka, Kyiv (in Rassian).

Veklich, M.F., Sirenko, N.A., 1972 Opornye geologicheskie razrezy antropogena Ukrainy.[Key geological sections of the Anthropogen of Ukraine Part III] Naukova dumka, Kyiv (in Rassian).

Yatsko, I.Ya., 1954. O nekotoryh predstavitelyah Unionidae iz neogena yuga USSR [About some representatives of Unionidae from the Neogene of the south of the Ukrainian SSR] Proceedings of Odessa University. Series of geological and geographical. Vol. 2. 71-107 (in Russian). 